\title{
Improving the Quality of the Integrated Junior-High School of Lampang, Subang, West Java, in Achieving National Education Standards
}

\author{
Asep Priatna \\ STKIP Subang \\ stkipsubang@yahoo.com \\ asep_priatna@yahoo.co.id
}

\begin{abstract}
This study aims to reveal the efforts and results achieved by the Integrated Private Junior-High School of Lampang, Subang, in improving its learning quality to meet the National Education Standard (SNP -Standar Nasional Pendidikan). It is the process on how the school gets the status of a national standard school (SSN-Sekolah Standar Nasional). This research was a survey with a qualitative approach. The study was conducted in the Integrated Private Junior-High School of Lampang, Subang, West Java. The data sources were the principal, the vice-principal, the teachers, and the school and student committees. The research instrument was based on eight components of SNP that refer to the National Education Standards. The development of research instruments was adapted to the concept of SNP, to build measured variable construction. They are generally described in components, aspects, and indicators of each SNP. The same development was also applied in the school performance instrument. Consequently, in the context of school performance, the achievement benchmark is the SNP. The data analysis used in this research is descriptive analysis. The results shown hat the level of achievement of the program that has been compiled in the Integrated Private Junior-High School of Lampang has reached $90 \%$. The main target is National Final Examination (UAN -Ujian Akhir Nasional) and graduation levels that have been implemented by teachers both in the preparation of lesson plans and teaching materials. Achievement of learning material availability $85 \%$. The management that has been developed by the Integrated Private Junior-High School of Lampang contributes significant value, especially in the planning and the implementation of the program. The supervision and leadership of the principal has been going well, so that the value obtained is significant. The other components that are quite prominent are the Learning and Teaching Process (PBM -Proses BelajarMengajar); and the content standard get a good value.

Keywords: implementation of quality management, SSN, SNP
\end{abstract}

\section{INTRODUCTION}

Education has a major role in building a nation, because education will produce good human resources. Superior human resources are expected to be able to build the nation. Therefore, in the current global era, when a government does not care about the development of the education sector in serious and sustained manners, in the end it will trap the majority of people to enter the world of underdevelopment in various aspects of life. If the state ignores to education, then the nation will never advance.
Investment in education will produce very positive results for the nation's progress.

Overall, based on the data from the Directorate General of Elementary and Secondary Education Management, the Ministry of Education and Culture (2013), the quality of education in Indonesia has been reviewed based on the results of the accreditation. There are 35,601 juniorhigh schools. Among them, there are 5,243 (14.73\%) with Grade A, 16,247 (45.64\%) with Grade B, 11,090 (31.15\%) with Grade C, and 3,021 (8.49\%) with unknown grade/not accredited. There are 3,699 junior-high schools that have met the SSN criteria. Previously, the government's target, based on the Strategic Plan, is more than $75 \%$ of the schools that can meet eight of SNPs or can become SSN in 2015. The eight SNPs are standard of graduate competency, standard of content, standard of processes, standard of facility and infrastructure, standard of educators and school stakeholders, standard of management, standard of finance, and standard of assessment.

The Directorate of Junior High School Development in recent years has been carrying out guidance for schools with categories of SPM and of Potential Junior-High School to meet the SNP. Likewise, prior to 2011, The Directorate has conducted school guidance to meet the SSN criteria for nearly 10 years.

The compliance of the SNP is part of the government's efforts in improving the quality of education in Indonesia. Improving the quality of education as an integral part of community development efforts is aimed to improve the quality of human resources (HR) that is able to answer the challenges of competition in the field of economic, social, cultural, and technological. Those are increasingly competitive, regionally, and internationally. Therefore, any effort to improve the quality of education is a strategic issue. It has been identified that one of the weaknesses in Long-term Regional Development Plan (RPJPD -Rencana Pembangunan Jangka Panjang Daerah) is the high level of competition due to globalization.

Educational problems that still exist today and in the future in Indonesia generally are matter of equity, quality, relevance, efficiency, quality, management, and financing of education. The problem occurs in nearly every track, level, and type of education. Many factors lead to the educational problems. These factors include the quality and quantity of the 
learners, the staffs, the curriculum, the educational facilities, community participation, management, and financing.

In quantitative terms, the development of education provision has shown encouraging results. According to the data from the Office of Education, the Regency of Subang, West Java, in 2014, the number of schools in each education level is increasing. The number of kindergartens and raudhatul athfals (Islamic kindergarten) is increased by $85.06 \%$ (131 schools). The number of Elementary Schools and Madrasah Ibtidaiyahs (Islamic Elementary School) is increased by $10.69 \%$ (95 schools). The number of Junior High Schools and Madrasah Tsanawiyahs (Islamic Junior High School) is increased by $40.90 \%$ (54 schools). The number of Senior High Schools and Madrasah Aliyahs (Islamic Senior High School) is increased by $40.90 \%$ (18 schools). The number of Vocational Senior High Schools is increased 7.5\% (3 schools). The increases in the number of schools surely are followed by the increase in the number of students at each level of education.

Other problems are also encountered. They cover the amount of education index that consists of two components, namely the average length of school period and the literacy rate for the population aged 15 years and above. The magnitude of RLS figure only reached 6.72. The figure illustrates how long students spend their time in education: the longer a student spends times for education, the higher quality of education he/she receives. Based on the numbers in the data, the provision of education in junior high schools has not shown a significant development yet. It can be assumed that the secondary education in Subang has not fully accessible by the public yet. There are various reasons. One of them is that education is relatively expensive, especially for the lowermiddle class. People have not fully realized the importance of secondary education as a means of developing child's mental and attitude before continuing to higher education level or work.

To deal with these threats, Subang regency government's strategic policy in education is to optimize the quality improvement, relevance, and competitiveness at all levels of education. Improving quality and relevance is measured by higher academic and non-academic skills, which allows graduates to be proactive to changes the society. Increase in the access of education should be offset by increase in the quality of education. Therefore, the number of schools that can meet the SNP needed to be boost, as well as the target indicator of the increasing number of SSN on all levels of education.

Efforts to improve these achievements are closely related to the improvement of other aspects of educational development. They include school performance, indicator to be accredited "A", the average achievement of UAN in last three years that has reached 7.00 , the percentage of graduation that reach above $90 \%$, the interest of the past three years that is larger than the capacity, academic and non-academic achievement, implementation of school-based management, the relevance of graduate skills and qualifications of teachers, and the ideal ratio of teachers and students.
The Strategic Plan of Subang Regency's Education Office establishes the vision of "Kabupaten Subang Tuntas Rintisan Wajib Belajar 12 tahun dan Unggul dalam Mutu Pendidikan" ("Subang Regency's will Completed 12 years of Compulsory Education and Education Quality Excellence"). It has three main objectives that cannot be separated. The first is that education must open up greater opportunities to whole people to obtain educational services. The second is normative that the provision of education should be conducted with reference to the SNP. This dimension suggests that the increase in participation from the society in education should be offset by an increase in the quality of education provision. Thus, the substance of educational goals can be realized for all types, tracks, and educational levels.

The third dimension is the applicable dimension where education must have individual functions and social functions, in accordance with the educational goals in Educational Act Number 20 of 2003 on National Education System. In Chapter II, the law states that national education aims to develop student's potentials to become a man of faith and devoted to the God Almighty, the noble character, healthy, knowledgeable, capable, creative, independent and become citizens of a noble, healthy, knowledgeable, capable, creative, independent, and democratic and accountable.

Subang District is one of 30 districts in Subang Regency. It has a population of 49,960 inhabitants. It consists of 24.758 men and 25.202 women. Subang District has the potential and excellent products in agriculture, and plantation.

Potential educational facilities in this district include 16 junior high schools. It consists of 6 public and 10 private junior school covering 1702 students. Most junior highschools in the district also accept students from other regions surrounding it. It is because many outside regions have sizeable number of 24 elementary schools covering 1,412 students. One of junior high schools that have a very good potential in the process of learning and achievement is the Integrated Junior High Schools of Lampang. It is a private junior high school in Subang District. It is expected to provide high-quality educational services for the community of Subang District in particular and for the Subang Regency in general.

School is a smaller part of the total education of children than those already assumed by most teachers and parents. So far, the school has been entrusted to carry out the task of educating, and from generation to generation is considered to have fulfilled its duty ethically and honestly. Education in schools has become such an integral feature of socio-economic landscape, making it almost impossible to arrange another approach to educating children, at least as long as they are still in education, especially teenage. Both primary and secondary levels, as well as higher education, are expected to produce a generation that is ready to face changes.

The $21^{\text {st }}$ century is an openness era, the era of borderless world that is called globalization. According to Tilaar, the $21^{\text {st }}$ century life demands human being to be superior with superior workmanship. This is due to society of the 21 st century is an open society that provides various types 
of possible choices. Only leading people can survive in a life that is full of competition and demand quality of life, both in product and in service in the common life.

Policy strategies undertaken to reach an excellent school is based on government regulation number 19 of 2005 on national education standards. (1) The learning process is conducted in a way that feels life, motivating, interactive, inspiring, fun, and challenging. It should also provide enough space for initiative, creativity, and independence of learners in accordance with their talents, interests, and physical development. (2) The learning process provides exemplary education. (3) To implement effective and efficient learning process, every unit of education conducts planning, implementation, assessment of the learning process, and good supervision.

Based on the above policy strategies, excellent school is expected to be able to transform into several targets. (1) The school is expected to be able to provide optimal services to all children with different talents, interests, and learning needs. (2) The school is expected to be able to increase significantly the capabilities possessed by students as their self-actualization that gives pride. (3) The school is expected to be able to build personality that is strong, solid, and steady in student's life. (4) The school is expected to be able to empower existing resources optimally and effectively. (5) The school is expected to be able to develop comprehensive networking to stakeholders. (6) The school is expected to be able to realize itself as a learning organization. (7) The school is expected to be able to respond changes. According to Mohrman, there are 8 (eight) essential principles of schools that have high performance: (1) an intellectual focus directed at helping students to use their minds well; (2) simple goals related to students mastering a limited number of skills and knowledge; (3) universal goals for all students in the school; (4) personalization through decreasing the number of student teacher teaches; (5) viewing the students as worker rather than passive record of information; (6) student exhibitions that indicate a grasp of knowledge and skill acquisition; (7) an attitude that stresses trust and decency; and (8) a staff who are generalist first and specialist second.

\section{RESEARCH METHOD}

This study uses survey research with a quantitative approach. As stated by Masri Singarimbun, survey may be used for the purpose of (1) assessment (exploratory); (2) descriptive; (3) an explanation (explanatory or confirmatory), which describe causal relationships and testing hypotheses; (4) evaluation; (5) the prediction or forecast of certain events in the future; (6) operational research, and (7) development of social indicators.

This research was conducted in the Integrated Junior High School of Lampang Subang, West Java, which is located in the Village of Lampang, Sub-district of Parung, Subang, West Java. The study was conducted from April to September 2014.

The study is aimed to obtain comprehensive data on the condition of the school and other things, through a data collection. Data collection is done by filling out a questionnaire based on information obtained from the respondents, field observation, and documentation study. Data source is obtained through questionnaires, interviews, and observations to some circles. The first is the Principal, to collect data related to the school's profile and to obtain data about the school, as well as supporting documents, particularly with respect to indicators that have become the principal duties. Secondly, interviews with teachers. Interviews with teachers are conducted to verify the data that are directly related to the duties of teacher as a teaching staff and as a sub-system of the school, particularly in the development of school and learning. Third, interviews with the School Committee to verify the data directly related to the role of the school committee as the supporter of the school development. Fourth, interviews with students to verify the data directly related to the role of teachers, particularly in the implementation of the learning process. Fifth, interviews with the officials of the Education Office of Subang regency, related to the implementation, development, and authority, including on: policy, curriculum, funding, educators and education personnel, facilities and infrastructure, and supervision.

The development of research instruments is adapted to the concept of SNP, to construct the measured variables, which are generally described in the component, aspect, and indicator of each SNP, as well as for the development of school performance instrument. Thus, in the context of school performance, the achievement benchmark is the SNP.

The instrument is based on eight components that refer to SNP, both contained in Law 20/2003, Regulation 19/2005 and Government Regulation 32/2013 as well as all Decrees of the Minister of National Education regulating eight (8) SNPs to measure the achievement of compliance of SNP indicators. The eight SNPs are standard of graduate competency, standard of content, standard of processes, standard of facility and infrastructure, standard of educators and school stakeholders, standard of management, standard of finance, and standard of assessment (further, see Buku Indikator SNP -the Book of SNP Indicators).

In addition, the instrument was also developed based on understanding of the concept of management education and considering the field conditions in the practice of schooling. SNP instruments contain several components that include several aspects of education. Every single aspect contains indicators of SNP, which subsequently was developed into questions/statements.

\section{RESULTS AND DISCUSSION}

The Integrated Junior High School of Lampang as one of private junior high schools has received accreditation with the classification of "A" (very good). It has a huge opportunity to be a school that has good quality in accordance with SNP, to be categorized as an SSN. This was demonstrated by several things found during the research process. Among others, they are the land area owned by the 
school is very adequate, amounting $5,065 \mathrm{~m}^{2}$. The school's level of achievement in UAN during last 3 (three) years reached a very satisfactory value. The average in 2011/2012 reached 7.50; 7.77 in 2012/2013; 7.50 in 2014/2015 and 7.77 in 2013/2015. Thus, there is an increase in its student's achievement during their education process in the junior high school

\begin{tabular}{|c|c|c|c|c|c|c|c|c|c|c|}
\hline \multirow[t]{2}{*}{ Academic Year } & \multirow{2}{*}{$\begin{array}{l}\text { Number } \\
\text { Registrants } \\
\text { (Prospectiv } \\
\text { Students) }\end{array}$} & \multirow{2}{*}{$\begin{array}{r}\text { of } \\
\text { New }\end{array}$} & \multicolumn{2}{|c|}{ Grade VII } & \multicolumn{2}{|c|}{ Grade VIII } & \multicolumn{2}{|c|}{ Grade IX } & \multicolumn{2}{|c|}{$\begin{array}{c}\text { Total } \\
(\text { Grd. VII + VIII + IX) }\end{array}$} \\
\hline & & & $\begin{array}{c}\text { Number of } \\
\text { Student }\end{array}$ & $\begin{array}{l}\text { Learning } \\
\text { Groups }\end{array}$ & $\begin{array}{c}\text { Number of } \\
\text { Student }\end{array}$ & $\begin{array}{l}\text { Learning } \\
\text { Groups }\end{array}$ & $\begin{array}{c}\text { Number of } \\
\text { Student }\end{array}$ & $\begin{array}{l}\text { Learning } \\
\text { Groups }\end{array}$ & $\begin{array}{c}\text { Number of } \\
\text { Student }\end{array}$ & $\begin{array}{l}\text { Learning } \\
\text { Groups }\end{array}$ \\
\hline $2012 / 2013$ & & 90 & 80 & & 47 & 2 & 48 & 2 & 175 & 2 \\
\hline $2013 / 2014$ & & 90 & 80 & & 80 & 2 & 47 & 2 & 207 & 2 \\
\hline $2014 / 2015$ & & 70 & 60 & & 80 & 2 & 72 & 2 & 212 & 2 \\
\hline $2015 / 2016$ & & 90 & 80 & & 60 & 2 & 80 & 2 & 220 & 2 \\
\hline
\end{tabular}

The implementation of learning in various subjects conducted in Grade VII, VIII, and IX, especially in subjects of sciences, socials, and local contents, has implemented ITbased learning and contextual learning. The junior high school is located approximately $5 \mathrm{~km}$ from the central of Subang City, in the village of Parung. Access to the school can be served either by private vehicle or by public transportation

that serve the route Subang-Jalancagak every day. The physical condition of the school and the existing learning tools is sufficient. It has six learning groups, with 40 students in each. The amount is adjusted with the capacity and interest of students as part of an effort to provide opportunities to all segments of society in gaining access to compulsory education so that the program can be completed.

Table 2. Academic Achievement: Score of UAN

\begin{tabular}{|c|l|c|c|c|c|c|c|}
\hline \multirow{2}{*}{ Nr. } & Academic Year & \multicolumn{3}{|c|}{ Score of UAN } & Total & Average \\
\cline { 3 - 8 } & & $\begin{array}{c}\text { Indonesian } \\
\text { Language }\end{array}$ & Mathematics & English & Science & & \\
\hline 1. & $2013 / 2014$ & 50,57 & 50,15 & 50,33 & 50,15 & 201,20 & 50,30 \\
\hline 2. & $2014 / 2015$ & 66,53 & 36,03 & 38,44 & 39,69 & 179,69 & 44,92 \\
\hline
\end{tabular}

Table 3. Academic Achievement: Rating of Average Score of UAN

\begin{tabular}{|c|c|c|c|c|c|c|c|c|c|c|}
\hline \multirow[t]{3}{*}{$\mathrm{Nr}$. } & \multirow[t]{3}{*}{ Academic Year } & \multicolumn{9}{|c|}{ Peringkat } \\
\hline & & \multicolumn{3}{|c|}{ District Level (Region) } & \multicolumn{3}{|c|}{ Regency/City Level } & \multicolumn{3}{|c|}{ Province Level } \\
\hline & & $\begin{array}{l}\text { Public } \\
\text { School }\end{array}$ & $\begin{array}{l}\text { Private } \\
\text { School }\end{array}$ & $\begin{array}{c}\text { Public and } \\
\text { Private School }\end{array}$ & $\begin{array}{l}\text { Public } \\
\text { School }\end{array}$ & $\begin{array}{l}\text { Private } \\
\text { School }\end{array}$ & $\begin{array}{c}\text { Public and } \\
\text { Private School }\end{array}$ & $\begin{array}{l}\text { Public } \\
\text { School }\end{array}$ & $\begin{array}{l}\text { Private } \\
\text { School }\end{array}$ & $\begin{array}{c}\text { Public and } \\
\text { Private School }\end{array}$ \\
\hline 1 . & $2013 / 2014$ & 26.95 & 26.30 & 26.62 & 25.81 & 25.85 & 25.83 & 26.38 & 26.07 & 26.22 \\
\hline 2. & $2014 / 2015$ & 54.16 & 48.00 & 51.00 & 48.16 & 50.00 & 49.08 & 51.16 & 49.00 & 50.00 \\
\hline
\end{tabular}

Although the school has not achieved the feat in recent years, but the passion for progress and achievement is very high. It is proved by the increasing diversity of efforts made by the school in promoting its potential, although it has

not achieved maximum results yet. However, it does not relax the spirit and confidence of all components of the Integrated Junior High School of Lampang to become an SSN school.

Table 4. Figures Graduation and Continuation

\begin{tabular}{|c|c|c|c|c|c|c|}
\hline \multirow[t]{2}{*}{ Nr. } & \multirow[t]{2}{*}{ Academic Year } & \multicolumn{5}{|c|}{ Number of Graduation and Continuation of Study } \\
\hline & & $\begin{array}{c}\text { Number of } \\
\text { Examination } \\
\text { Participants }\end{array}$ & $\begin{array}{l}\text { Number of } \\
\text { Graduation }\end{array}$ & $\%$ Graduation & $\begin{array}{c}\% \text { Graduates that } \\
\text { Continue Their } \\
\text { Education }\end{array}$ & $\begin{array}{l}\text { \% Graduates that } \\
\text { Does Not Continue } \\
\text { Their Education }\end{array}$ \\
\hline 1. & $2013 / 2014$ & 47 & 47 & $100 \%$ & $75 \%$ & $25 \%$ \\
\hline 2. & $2014 / 2015$ & 72 & 72 & $100 \%$ & $85 \%$ & $15 \%$ \\
\hline
\end{tabular}

Some of the subsequent development programs are aimed at achieving the UAN and non-academic achievement. Efforts that are being intensified in the academic field are the formation of study groups. It is expected to elevate passion for learning and achievement in various Olympics fields held at the regency, provincial, and even national levels.

Specifically, the development of RKAS related to eight SNPs at this school has been executed. The results have been felt by the whole community in a few years, so the community expects the school can be developed into an excellent school.
Some findings in this research can be delivered as follow.

1. Achievement in the Graduate Competency Standards is in the satisfactory value. The level of achievement of graduates during the last three years has reached 100\% with the average attainment for four subjects have reached 8.48. The highest scores are in subjects of Science, Mathematics, and English.

2. Percentage of the Content Standards includes "completeness" of KBK components (basic concepts, syllabus, annual program, semester program/mapping, assessment, lesson plans, etc.) for grade 7, 8, and 9 
(documentation), the percentage of teachers who have had a complete documentation of the KBK. The percentage of implementation of KBK in the school has been achieved well in which all teachers and school leaders have quite understood all components and possessed them.

3. In the aspects of Teaching and Learning, the school has implemented learning programs in accordance with their capabilities and targets set in the SNPs, despite the limited facilities and infrastructure. The limited facilities and infrastructure cover particularly in terms of percentage of teachers who have implemented CTL in the learning process, the percentage of teachers who have used instructional media, the percentage of ownership of learning media for all subjects, the average percentage of teacher attendance in teaching that has reached $90 \%$.

4. Teachers and educational staffs as a fundamental aspect in the implementation of learning have the strategic position. Therefore, the development of the educator ability is one of the serious concerns. The concerns cover the ratio of the number of teachers and study groups, the percentage of under graduated qualified teachers (of the total number of teachers), the percentage of compliance of teacher's areas of expertise with the task of teaching. They all have achieved good levels. The development of the ability of teachers even has reached the highest education levels. The training of CTL and KTSP has been carried out properly. In the further development of teacher education, they has been planned to reach master degree.

5. Facilities and infrastructures of the school, which is considered far away from the center of the town and located in the most eastern side of the town, face transportation barriers. Therefore, the information and the development of facilities and infrastructure become a serious problem. The problem, especially, lies in meeting the needs of laboratories (both Science and ICT). Especially the ratio of classrooms to the study groups, the number of science laboratories, the number of computer laboratories, the number of language laboratories, internet for students, the ratio of books to students, the number of computers for students. They all have been fulfilled with the use of ICT-based development, so that every class and room has been connected to the Internet that is supportive in the development of student learning.

6. Management as a system in the school has an important role in supporting the implementation of programs to achieve the vision and the mission of the school to be in line with national education goals. In this management, the school principal has an important role with the support of all staffs and school components, including students. Some documentation of the school administration, the percentage of involvement (participation) of the stakeholders in decision-making runs in synergy between the schools and the stakeholders. The cooperation with the school committee is very significant in the development of the school.
7. Financing Education is an important aspect in the provision of education and the learning process. Nevertheless, since the emergence of BOS and free education, people's creativity in developing and supporting the school in its development process are shut off. They are especially covers the supports from the local government, both the provincial and regency levels, mostly in the observations of the annual draft of school budget (RAPBS -Rencana Anggaran Pendapatan dan Belanja Sekolah). Although, in the implementation of further financing process, the school has been able to draw quite large funds from the public. The number of funding sources in the school has even become more varied.

8. Assessment as something that is needed in viewing the achievement of the learning process during the running time has a very important role. Therefore, the observation of the percentage of teachers who have implemented the authentic assessment or class-based assessment, percentage of document completion in this school has reached a good achievement. Especially in KKM, it has reached more than 75 . Student achievement have reached more than $85 \%$.

As a school that has been developed over several years, the Integrated Junior High School of Lampang has decent to be an SSN based on a number of considerations, including the general readiness in the school development. Another potential that can be developed by the school along with school components is the achievement of accreditation of A, the accreditation assessment even reach the category of Very Good.

\section{CONCLUSIONS AND SUGGESTIONS}

The implementation of the school programs in achieving SNP has been done well and running smoothly. The implementation of the programs, which has been implemented in all classes, have given considerable impact exhibited to the improvement of the academic and non-academic qualities. The level of achievement of the program that has been compiled in RPS has reached $90 \%$. The main target is the achievement value of UAN and graduation. It has been implemented by teachers in the preparation of lesson plans and teaching materials to reach $85 \%$. The implementation of other programs is still also running well. Academic potentials that can be developed include the participation in each competition and Olympic in the levels of regency, provincial, and even national, with the coaching and good support from the teachers, the Education Office of the regency, as well as parents and school committee

Management developed by the Integrated Junior High School of Lampang contributes considerable significant value, especially in the planning and implementation of the programs. The supervision and leadership of the principal has also been going well, so that the value obtained is significant. The other quite prominent components are the PBM and content standard. They have reached good scores, so they can be developed further. 
Based on the analysis of data, and the overall school conditions through observation and integrated evaluation, the Integrated Junior High School of Lampang has implemented school programs in good manners. It is conducted with the support of all stakeholders covering the parents, the community, the government (regency, provincial, and national). Therefore, it can be said that the school deserve to be SSN with some further development, especially infrastructure that cover laboratories of language, science, ICT and Mathematics. It can be performed despite the public support in financing is considered as minimal, due to the lack of understanding of some people in facing free school program.

\section{REFERENCE}

[1] Suyanto, (2008), Dialog Interaktif Tentang Pendidikan (dari konseptual menggelitik sampai yang ringan dan ringan sekali). Yogyakarta: Multi Pressindo; $\mathrm{p}: 8$

[2] Cohn, Elchanan. (1979). The Economics of Education. Massachusetts, Cambridge: Ballinger Publishing Company; p:16

[3] Tilaar, H.A.R., (2006). Standarisasi Pendidikan Nasional: Suatu Tinjauan Kritis. Jakarta: Rineka Cipta; p:63

[4] Jalal, F. (2005). Kebijakan Pendidikan dalam Profesionalisasi Pendidik dan Tenaga kependidikan dalam Upaya Meningkatkan Kualitas Pendidikan. Bandung: FIP UPI; p:18

[5] Jalal, F. (2005). Kebijakan Pendidikan dalam Profesionalisasi Pendidik dan Tenaga kependidikan dalam Upaya Meningkatkan Kualitas Pendidikan. Bandung: FIP UPI; p: 18

[6] Singarimbun, Masri (1995). Metode penelitian Survey. Pustaka LP3ES, Jakarta; p:6 